\title{
水泥生产过程中低温烟气用余热锅炉性能的全尺寸 数值模拟
}

\author{
杜文静 ${ }^{(12)}$ ，赵春雷 ${ }^{(1)}$, 程林 ${ }^{(1) *}$ \\ (1) 山东大学热科学与工程研究中心, 济南 250061; \\ (2) 山东大学能源与动力工程学院, 济南 250061 \\ * 联系人, E-mail: cheng@sdu.edu.cn
}

2015-05-23 收稿, 2015-06-18 修回, 2015-06-19 接受, 2015-08-18 网络版发表 国家重点基础研究发展计划(2013CB228305)资助

\begin{abstract}
摘要随着能源利用的日益紧张, 工业余热的高效综合利用受到较多关注. 作为一种典型余热回收利用装置, 余热锅炉的应用日益广泛。鉴于余热锅炉容量大、结构复杂，相关的数值建模较困难。本文提出一种新的余热锅炉 数值模拟方法，用于实现余热锅炉的全尺寸数值模拟。研究得到了余热锅炉用换热管束间的流场和温度场的分布 特征, 给出了余热锅炉的流动和传热特性. 分析了烟气入口温度和流量对锅炉性能的影响, 结果表明余热锅炉的 综合性能随着入口烟气温度的升高而升高, 随着烟气流量的增加而增加.
\end{abstract}

关键词余热锅炉, 数值模拟, 余热回收

在当前能源供应紧张、环境问题严峻的形势下, 研究余热回收的任务紧迫而重大. 余热锅炉作为一 种热量回收的关键设备, 在过去几十年里得到了迅 速发展. 随着有色冶金能力的提高, 余热锅炉的参数 和容量也不断提高, 其性能直接影响到我国的能源 利用水平. 因此, 需要对余热锅炉进行深人的研究.

目前, 对余热锅炉的相关研究有3种方法：理论 计算、实验研究及数值模拟. 理论计算主要包括对余 热锅炉的结构、热力、烟道阻力和水循环等各方面进 行设计计算, 其中热力计算是学者研究的重点. 蔡睿 贤课题组 ${ }^{[1,2]}$ 根据能量守恒和质量守恒推导了一定条 件下的余热锅炉运行特性的解析解. 徐玉杰等人 ${ }^{[3]}$ 根 据实验数据, 拟合出修正系数, 提出了一种燃气轮机 无补燃余热锅炉联合循环的估算方法. 刘凤强等人 ${ }^{[4]}$ 建立余热锅炉优化模型, 得出了余热锅炉的最优化结 构参数. 蔡晖 ${ }^{[5]}$ 分析了影响传热系数的因素并对影响 辐射受热面传热系数的因素进行计算. 王士国 ${ }^{[6]}$ 通过
分析余热锅炉的热力回收，算得余热锅炉的热效率. 由于这些理论计算模型中包含了很多的主观性假设, 根据这些理论计算得到的数据只能部分符合实验数 据，仅能计算较简单结构的余热锅炉传热问题和辅助 进行锅炉的设计, 无法指导工业生产. 刘聿拯课题 组 ${ }^{[7,8]}$ 实验测试了余热锅炉在不同工况下的锅炉热效 率和系统效率. 刘博等人 ${ }^{[9]}$ 通过实验的方法研究了余 热锅炉对流区受热面的积灰特性. 裴讳等人 ${ }^{[10]}$ 对锅炉 管内腐蚀结垢进行了实验, 分析了结垢的影响因素, 研究了结垢的机理. 马斌和马启䂞 ${ }^{[11]}$ 研究了生物质直 燃炉受热面的腐蚀, 分析了腐蚀垢的特性, 提出了相 应处理方案. 由于余热锅炉本身容量大, 结构复杂, 进行一次现场实验研究难度较大, 耗时耗力而且浪费 资源. 计算流体动力学广泛应用于余热锅炉的模拟。 Gómez等人 ${ }^{[12]}$ 简化了余热锅炉结构, 通过与实际运行 数据对比, 验证了模型简化的合理性. Manickam等 人 $^{[13]}$ 模拟了带辐射室和对流区的冶炼余热锅炉, 得到

引用格式: 杜文静, 赵春雷, 程林. 水泥生产过程中低温烟气用余热锅炉性能的全尺寸数值模拟. 科学通报, 2016, 61: 1922-1930 Du W J, Zhao C L, Cheng L. Full-scale numerical simulations on the performance of the heat recovery boiler used in the cement production process (in Chinese). Chin Sci Bull, 2016, 61: 1922-1930, doi: 10.1360/N972015-00462 
了烟气的温度场和流场, 分析了积灰的可能性. $\mathrm{Xu}$ 等 人 ${ }^{[14]}$ 以一台 $350 \mathrm{MW}$ 煤粉炉为例, 模拟了不同负荷情 况下的燃烧和烟气流动, 与实际运行数据对比, 验证 了数值模拟方法合理性. Yang等人 ${ }^{[15]}$ 假设壁面边界条 件为恒壁温, 设定了人口湍流强度, 通过温度函数拟 合烟气特性, 采用不同湍流模型对余热锅炉进行了数 值模拟, 并用实测的锅炉温度场进行了验证. 国内的 余热锅炉研究起步较晚, 周樟华和彭鹏 ${ }^{[16]}$ 将模型中的 受热部件作多孔介质简化处理, 模拟了锅炉内烟气的 三维稳态定常流动. 崔成云等人 ${ }^{[17]}$ 将受热面简化为多 孔介质, 人为给定阻力系数, 采用标准 $k-\varepsilon$ 湍流模型对 人口烟道的流场进行了数值模拟. 杨卫宏等人 ${ }^{[18]}$ 通过 几何拓扑将流道多块结构化, 得到了余热锅炉内流场 和温度场. 另外, 针对余热锅炉的出人口烟道的角度 以及辐射冷却室的结构设计问题, 很多学者对余热锅 炉进行了大量数值模拟研究 ${ }^{[19 ~ 24]}$, 提出了优化方案. 同时, 针对余热锅炉的动态运行特性, 很多学者进行 了数值研究 ${ }^{[25 ~ 29]}$, 为锅炉设计及高效、可靠运行提供 了依据. 上述余热锅炉的数值模拟虽然为余热锅炉的 设计研发提供了依据, 但由于余热锅炉受热面管束数 量庞大, 管间流场复杂, 为了减小网格的难度和计算 量, 大多余热锅炉的模拟采用如下方法进行简化: (1) 模型受热面做多孔介质简化; (2) 将对流管束全部简 化为厚度与对流管直径相等且具有流动间隙的平板. 显然, 上述简化方法不能完整真实地反映余热锅炉内 部的流场和温度场, 不利于客观、真实地对余热锅炉 进行性能分析和结构优化.

本文以余热锅炉为研究对象, 通过数值方法, 建 立了余热锅炉的全尺寸数学模型, 对余热锅炉的流 场和温度场进行数值模拟, 获得了余热锅炉的整体 性能, 为余热锅炉的设计和运行提供数据支持.

\section{1 三维模型到二维模型的转化}

\section{1 余热锅炉物理模型}

图1为本团队研发的一种新型余热锅炉的物理模 型. 锅炉主要结构参数包括长度 $12.4 \mathrm{~m}$, 宽度 $2.5 \mathrm{~m}$, 高度为 $17.6 \mathrm{~m}$, 多种换热面布置在横截面为正方形的 管箱内. 该锅炉已安装在某水泥厂内并成功实现烟 气余热的回收. 余热锅炉所用热源为来自水泥回转 窑的中低温烟气, 烟气温度在 $150 \sim 400^{\circ} \mathrm{C}$ 波动. 图 2 给出了余热锅炉中两种主要换热面的结构示意图.

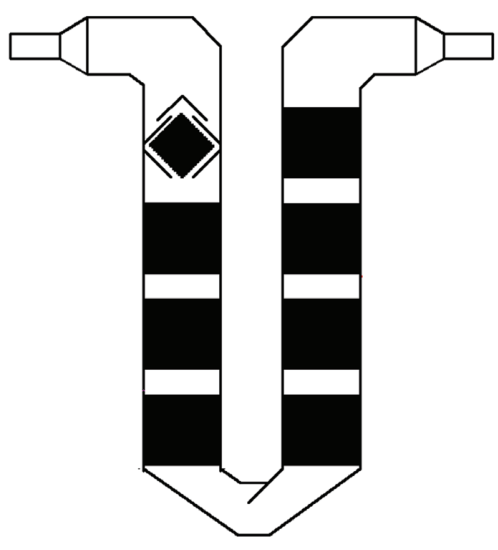

图 1 实验用余热锅炉的物理模型

Figure 1 Physical model of the heat recovery boiler

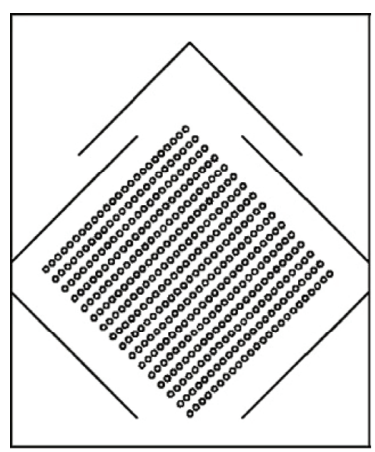

(a)

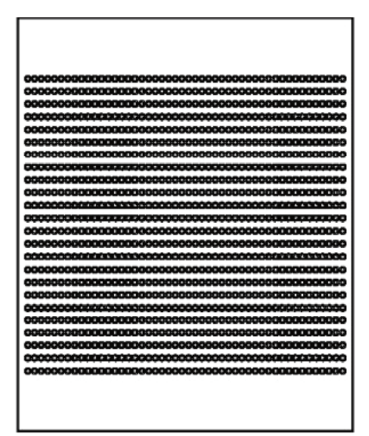

(b)
图 2 两种换热面结构示意图. (a) 第一种; (b) 第二种

Figure 2 Schematic diagrams of two heat transfer surfaces. (a) The first type; (b) the second type

\section{2 数值模型的建立}

本文采用Pro E建立图3所示的三维实体模型, 导 人ICEM对模型采用非结构网格进行划分，对换热域 进行网格加密. 通过网格独立性验证, 网格总数确定 为 2700 万. 图 3 给出了图 2 (b)换热面数值模型的三维 网格划分.

\section{3 控制方程}

余热锅炉中换热管束壳侧的烟气流动是复杂的 湍流运动. 相比于标准 $k-\varepsilon$ 模型, RNG $k-\varepsilon$ 模型是标准 $k-\varepsilon$ 模型的修正方程, 基于 $\mathrm{N}-\mathrm{S}$ 方程再归一化, 湍流生 成和湍流耗散方程与标准 $k-\varepsilon$ 模型相同, 但其常数系 数由 $C \varepsilon_{\mathrm{RNG}}$ 代替 $C \varepsilon$, 因此, RNG $k-\varepsilon$ 模型对于旋流流动 计算较标准 $k-\varepsilon$ 模型准确 ${ }^{[30]}$. 本文选用RNG $k-\varepsilon$ 模型 作为管束换热器的湍流模型. 对应的基本方程包括: 连续性方程如式(1)所示, 动量方程如式(2)所示, 湍 


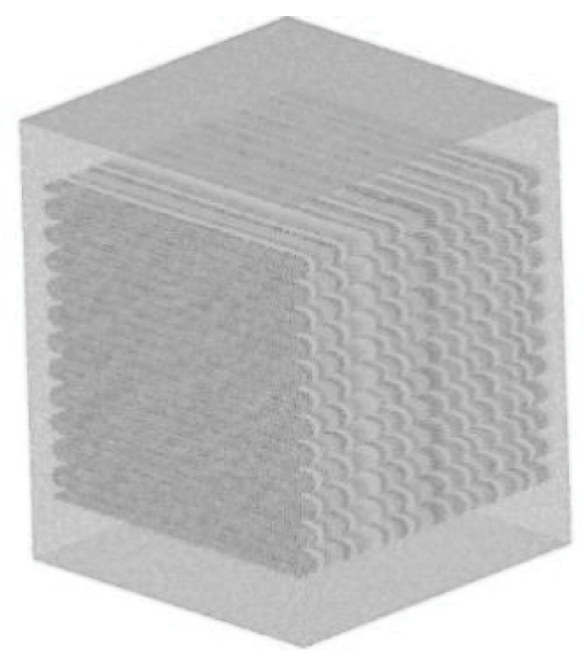

图 3 换热面的网格划分

Figure 3 Meshing of the heat transfer surface

动能方程与湍动能耗散方程如式(6)所示.

连续性方程:

$$
\frac{\partial \rho}{\partial t}+\nabla \cdot(\rho U)=0
$$

动量方程:

$$
\begin{aligned}
& \frac{\partial \rho U}{\alpha t}+\nabla \cdot(\rho U \otimes U)-\nabla \cdot\left(\mu_{\mathrm{eff}} \nabla U\right)=\nabla \cdot P^{\prime}+ \\
& \nabla \cdot\left(\mu_{\mathrm{eff}} \nabla U\right)^{T}+B,
\end{aligned}
$$

式中, $B$ 为体积力总和, $\mu_{\mathrm{eff}}$ 为有效黏度, $P^{\prime}$ 为修正压 力, 具体表达式下所示:

$$
\begin{aligned}
& \mu_{\mathrm{eff}}=\mu+\mu_{t}, \\
& P^{\prime}=P+\frac{2}{3} \rho k,
\end{aligned}
$$

式中, $\mu_{t}$ 是湍流黏度, $k-\varepsilon$ 模型假设湍流黏度与湍动 能和湍动能耗散有关, 即

$$
\mu_{t}=C_{\mu} \rho \frac{k^{2}}{\varepsilon} .
$$

湍动能方程与湍动能耗散方程

$$
\begin{aligned}
& \frac{\partial(\rho k)}{t}+\nabla \cdot(\rho U k)=\nabla \cdot\left[\left(\mu+\frac{\mu_{t}}{\sigma_{k}}\right) \nabla k\right]+P_{k}-\rho \varepsilon, \\
& \frac{\partial(\rho k)}{t}+\nabla \cdot(\rho U \varepsilon) \\
& =\nabla \cdot\left[\left(\mu+\frac{\mu_{t}}{\sigma_{\varepsilon \mathrm{RNG}}}\right) \nabla \varepsilon\right]+\frac{\varepsilon}{k}\left(C_{\varepsilon_{1} \mathrm{RNG}} P_{k}-C_{\varepsilon_{2} \mathrm{RNG}} \rho \varepsilon\right),
\end{aligned}
$$

式中, $\sigma_{k}$ 和 $\sigma_{\varepsilon}$ 为常数, $P_{k}$ 为黏性力和浮力的湍流产 物, 其方程为

$$
\begin{aligned}
P_{k}=\mu_{t} \nabla U \cdot\left(\nabla U+\nabla U^{T}\right)-\frac{2}{3} \nabla \cdot U\left(3 \mu_{t} \nabla \cdot U+\rho k\right)+P_{k b}, & \\
C_{\varepsilon_{1} \mathrm{RNG}}=1.42-f_{\eta} & \\
f_{\eta} & =\frac{\eta\left(1-\frac{\eta}{4.38}\right)}{1+\beta_{\mathrm{RNG}} \eta^{3}} \\
\eta & =\sqrt{\frac{P_{k}}{\rho C_{\mu \mathrm{RNG} \varepsilon}}}
\end{aligned}
$$

\section{4 边界条件}

鉴于烟气流速小于 0.3 倍马赫数, 可视为不可压 缩流体 ${ }^{[31]}$, 流动在计算工况范围内为湍流, 传热为 稳态传热, 忽略重力和浮升力的影响, 忽略黏性耗散 作用所产生的热效应. 鉴于烟气密度、导热系数、黏 度随温度变化较大, 如果将其视为常数则误差较大. 因此, 本文将烟气密度、导热系数、黏度拟合为温度 的一次函数, 其他参数设为常数. 人口为速度人口边 界, 出口为压力出口边界, 换热管外表面定义为恒壁 温边界条件, 其他各面定义为不可渗透、无滑移绝热 边界条件.

\section{5 数值模拟结果与实验结果对比}

图4为三维数值模型计算得到的烟气进出口温差 与实验值的对比. 由图4可知, 两者最大误差为 $9.4 \%$. 因此, 本文所建立的三维数值模型是可靠的. 实验值 比数值模拟结果较大的原因是模拟过程管箱边界条 件设为绝热, 实际情况存在管箱与外界的自然对流

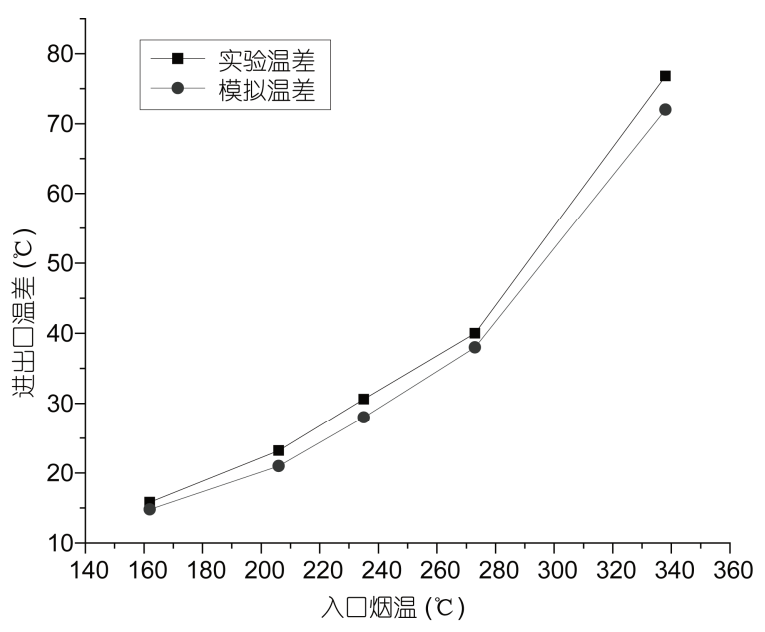

图 4 三维模型进出口烟气温差的计算值与实验值的对比

Figure 4 Comparisons between simulated and experimental values 
换热和辐射换热等.

\section{6 三维模型到二维模型的转化}

基于余热锅炉结构参数可知, 余热锅炉尺寸庞 大, 换热管数量较多, 建立其 $1: 1$ 全尺寸物理模型相当 困难. 如需真实模拟管屏和管间的流场, 必须加密流 动区域的网格, 对应网格数约为 3 亿, 增加了画网格 的难度和计算的成本, 因此整体模拟余热锅炉的流场 和温度场十分困难. 如需建立余热锅炉全尺寸物理模 型并进行相关流场和温度场的模拟, 必须进行必要的 简化. 鉴于换热管轴向长度为 $2250 \mathrm{~mm}$, 其轴向速度 场和温度场分布相对均匀. 如果其轴向温差较小, 则 三维模型可以转化为二维模型开展数值模拟分析. 表 1 给出了典型工况下余热锅炉沿换热管轴向截面的平 均温度分布. 由表 1 可知, 对应轴向温差小于 $0.1^{\circ} \mathrm{C}$, 可以忽略不计. 因此, 本文提出的三维模型到二维模 型的简化是可行的. 在后续研究中, 本文将采用余热 锅炉的二维全尺寸模型进行相关模拟分析.

\section{2 余热锅炉全尺寸数值模拟}

\section{1 网格划分}

余热锅炉体积庞大、结构复杂, 网格划分困难, 不仅对计算机要求高、耗时长, 网格质量也难以保证.

\section{表 1 换热区域沿轴向的温度分布}

Table 1 Temperature distribution of the heat transfer region along the axial direction

\begin{tabular}{cc}
\hline 轴向距离 $(\mathrm{m})$ & 温度 $(\mathrm{K})$ \\
\hline 0.25 & 411.88 \\
0.50 & 411.89 \\
0.75 & 411.96 \\
1.00 & 411.91 \\
1.25 & 411.97 \\
1.50 & 411.93 \\
1.75 & 411.93 \\
2.00 & 411.94 \\
2.25 & 411.90 \\
\hline
\end{tabular}

表 2 网格独立性验证

Table 2 Verification of mesh independence

\begin{tabular}{ccc}
\hline 网格数 & 进出口温差 $\left({ }^{\circ} \mathrm{C}\right)$ & 偏差 $(\%)$ \\
\hline 8900000 & 130.4 & 31.8 \\
16000000 & 150.6 & 20.8 \\
18500000 & 163.7 & 14.4 \\
21500000 & 187.5 & 1.4 \\
27000000 & 191.2 & - \\
\hline
\end{tabular}

为解决该问题，本文采用分块耦合的方法划分网格， 既提高了划分网格的速度，又保证了网格质量. 图5 为余热锅炉的整体网格. 为验证网格独立性, 对锅炉 进行网格划分，建立了数目分别为 890 万、1600万、 1850 万、 2150 万、 2700 万的 5 套网格系统. 当人口烟 温为 $300^{\circ} \mathrm{C}$, 流量为 $30000 \mathrm{~m}^{3} / \mathrm{h}$ 时, 对 5 套网格系统分 别进行数值计算, 得到进出口烟温温差随网格数的 变化规律(图6, 表2). 最后两组网格计算结果相差在 $2 \%$ 以内，综合考虑计算精度及计算效率，最终确定 网格数目为 2150 万.

\section{2 数值模拟结果与实验结果对比}

图7是二维全尺寸锅炉数值模型的烟气进出口温 差与实验值的对比曲线，最大偏差为 $2.8 \%$. 由此可

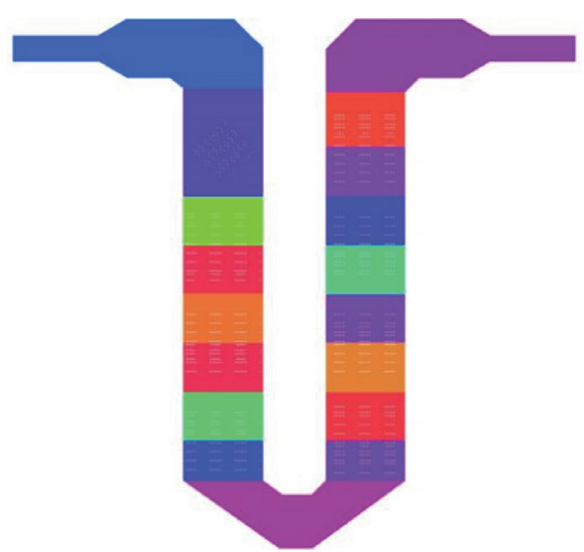

图 5 (网络版彩色)余热锅炉的整体网格

Figure 5 (Color online) Mesh of the heat recovery boiler

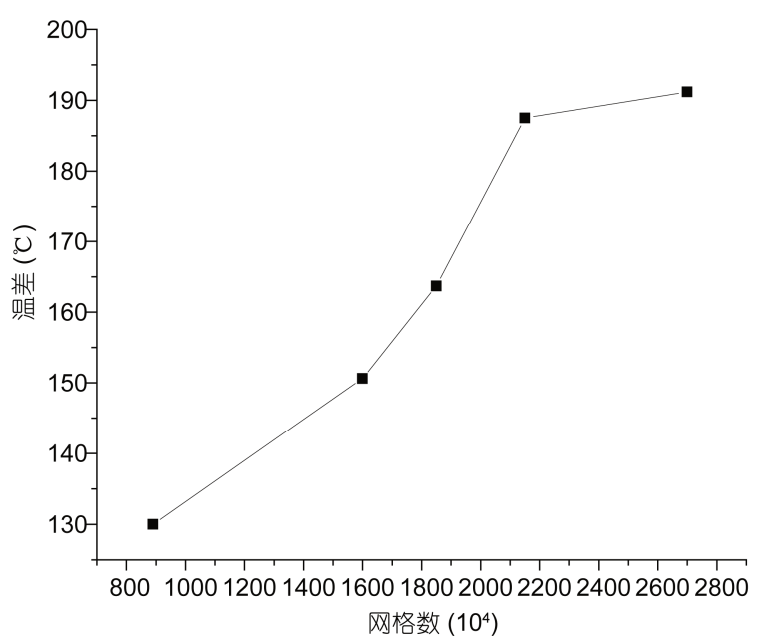

图 6 网格独立性验证

Figure 6 Verification of mesh independence 


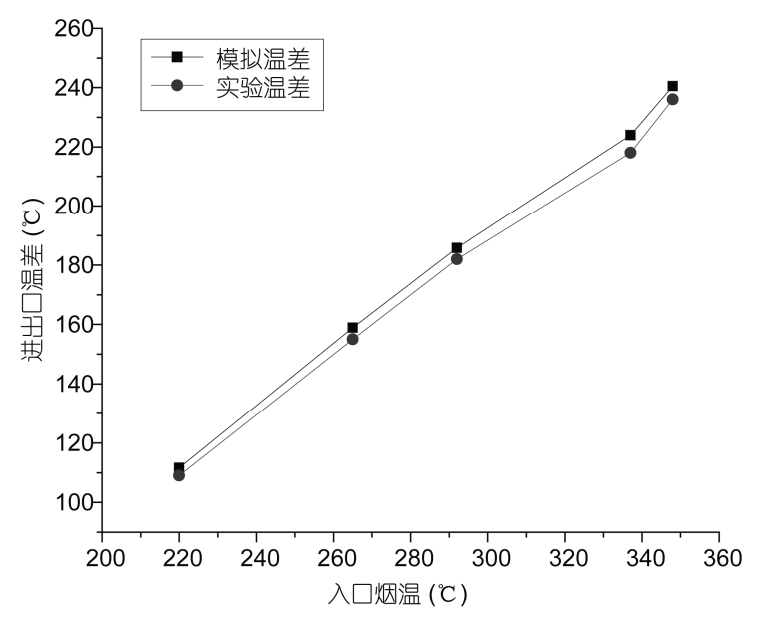

图 7 锅炉二维全尺寸模型中进出口烟气温差的计算值与实验值的 对比

Figure 7 Comparison between simulated and experimental values

知, 本文所建立的二维数值模型是可靠的. 实验值与 模拟值出现偏差的原因为模拟过程忽略漏风对换热 的影响. 在锅炉实际运行过程中, 漏风将引起烟温降 低, 换热效果变差, 导致烟气出口温度升高, 进出口 烟温降低. 由图4和7对比可知, 三维数值模拟的偏差 较二维模拟的偏差大. 其原因是三维网格数量较大, 为了兼顾计算成本和计算精度, 所画网格的网格质 量要比二维网格低.

\section{3 余热锅炉性能的数值模拟}

水泥回转窑工况不稳定, 对应烟气的流量和温 度不易控制, 导致了余热锅炉在不同流量和不同烟 温下实验的难度. 余热锅炉工况稳定耗时长, 进行不 同烟气流量和温度下的实验需要花费大量时间, 同 时由于本文用烟气人口温度较低, 难以完成较高烟 温工况下的实验, 因此, 本文采用数值分析的方法, 研究了 4 种烟气人口温度 $\left(250,300,350,400^{\circ} \mathrm{C}\right)$ 和 6 种 烟气流量 $(25000,30000,35000,40000,45000,50000$ $\mathrm{m}^{3} / \mathrm{h}$ ) 的工况, 给出了烟气温度和流量对余热锅炉表 面传热系数、压降和综合性能 $(\mathrm{JF} \text { 因子 })^{[32]}$ 的影响.

(i ) 余热锅炉内部温度场和速度场的分布. 通 过数值模拟发现, 余热锅炉内部温度场和速度场在 不同工况下分布规律较为接近, 因此, 本文选取烟气 流量为 $30000 \mathrm{~m}^{3} / \mathrm{h}$, 烟温 $350^{\circ} \mathrm{C}$ 工况的速度场和温度 场进行分析. 图8为该工况下余热锅炉内部的整体速 度云图和整体温度云图. 由图8(a) 可知, 烟气经左侧 人口烟道流经人口挡板折流和八级换热面, 最
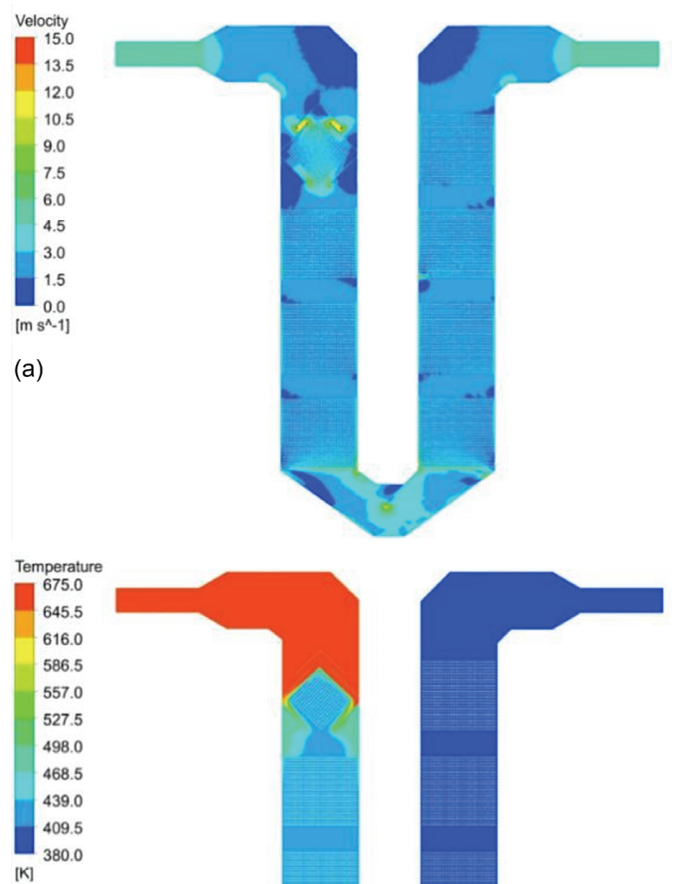

(b)

(a)

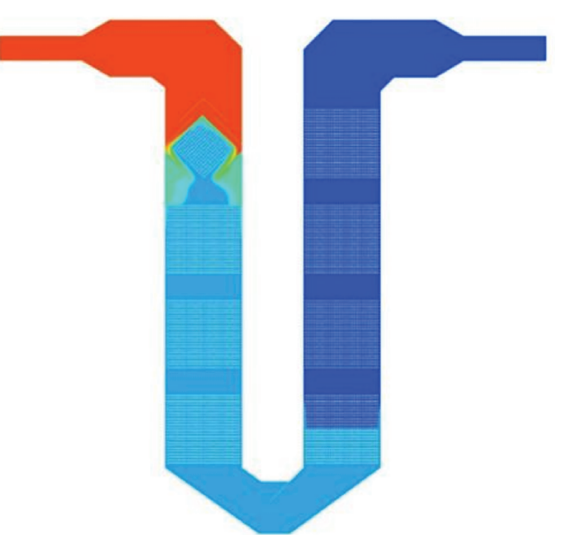

图 8 (网络版彩色)余热锅炉内部的速度云图和温度云图. (a) 速度 云图; (b) 温度云图

Figure 8 (Color online) Field distributions in the heat recovery boiler. (a) Velocity fields; (b) temperature fields

后由右侧出口排出. 锅炉内部的流场较为均匀, 在主 要换热区域没有出现大的漩浴, 有利于减少烟气走 廊, 进而减小对应的热偏差. 同时, 余热锅炉底部灰 斗加烟道挡板处产生了明显的漩涡, 这对烟气中的 固体颗粒起到阻流作用，有利用余热锅炉在底部的 排灰. 由图8(b)可知, 整个换热区域温度场分布较为 均匀, 换热面布置合理, 有利于减小热传递过程的不 可逆损失.

(ii) 烟气人口温度对余热锅炉性能的影响. 图 9 (a)给出了表面传热系数随烟气人口温度的变化曲 线. 在相同流量下, 随着温度升高表面传热系数增 大. 分析原因为烟温升高气体的比热增大, 导热系数 增大, 烟气对应的普朗特数 (Pr)减小. Pr是表征流体 动量扩散和热扩散能力对比的特征数, Pr减小意味着 流体的热扩散能力增强, 因此, 烟气温度升高表面传 热系数增大. 图9(b) 是烟气的压降随温度变化曲线. 在相同烟气流量下, 随温度升高压降减小. 分析原因 

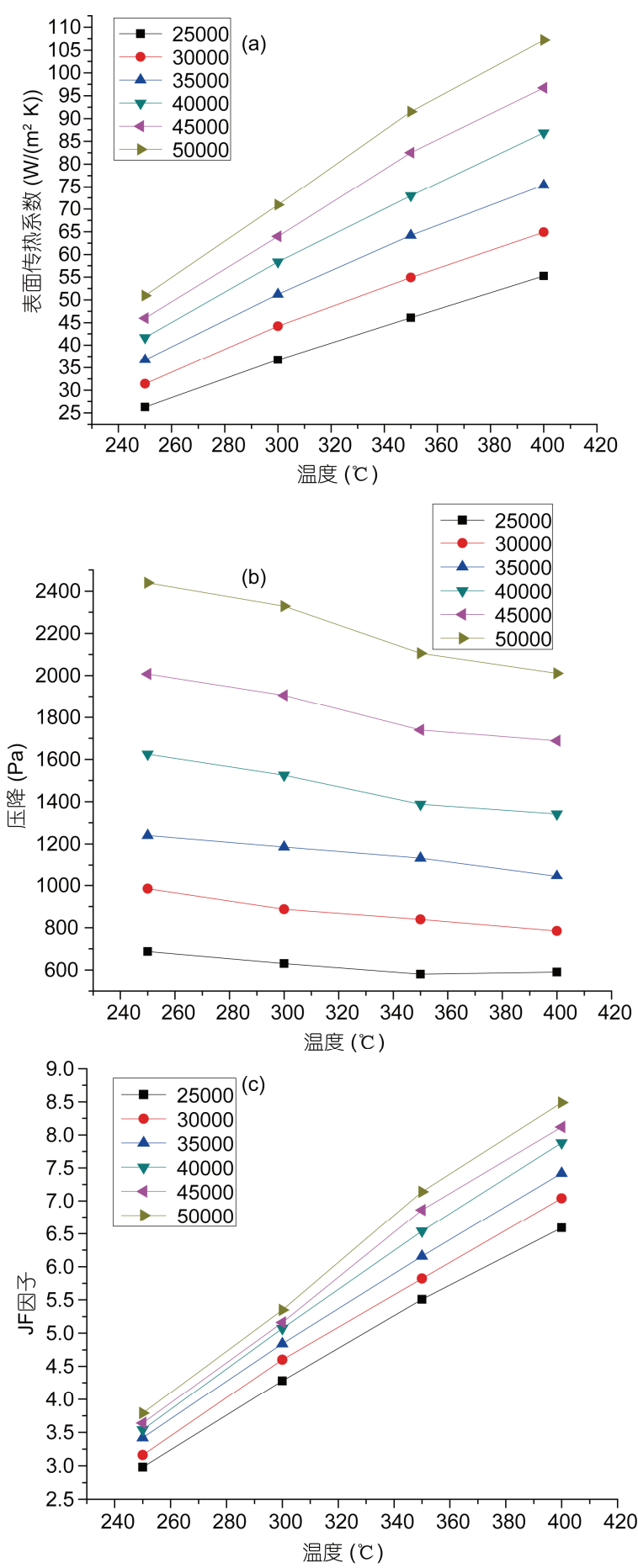

图 9 (网络版彩色)锅炉性能参数随烟温的变化. (a) 表面传热系数; (b) 压降; (c) JF 因子

Figure 9 (Color online) Variation of boiler performance parameters with the wind temperature. (a) Convective heat transfer coefficient; (b) pressure drop; (c) JF factor

为温度升高后气体黏度增大, 气体温度升高后气体 密度减小的程度比气体温度升高后黏度增大的程度
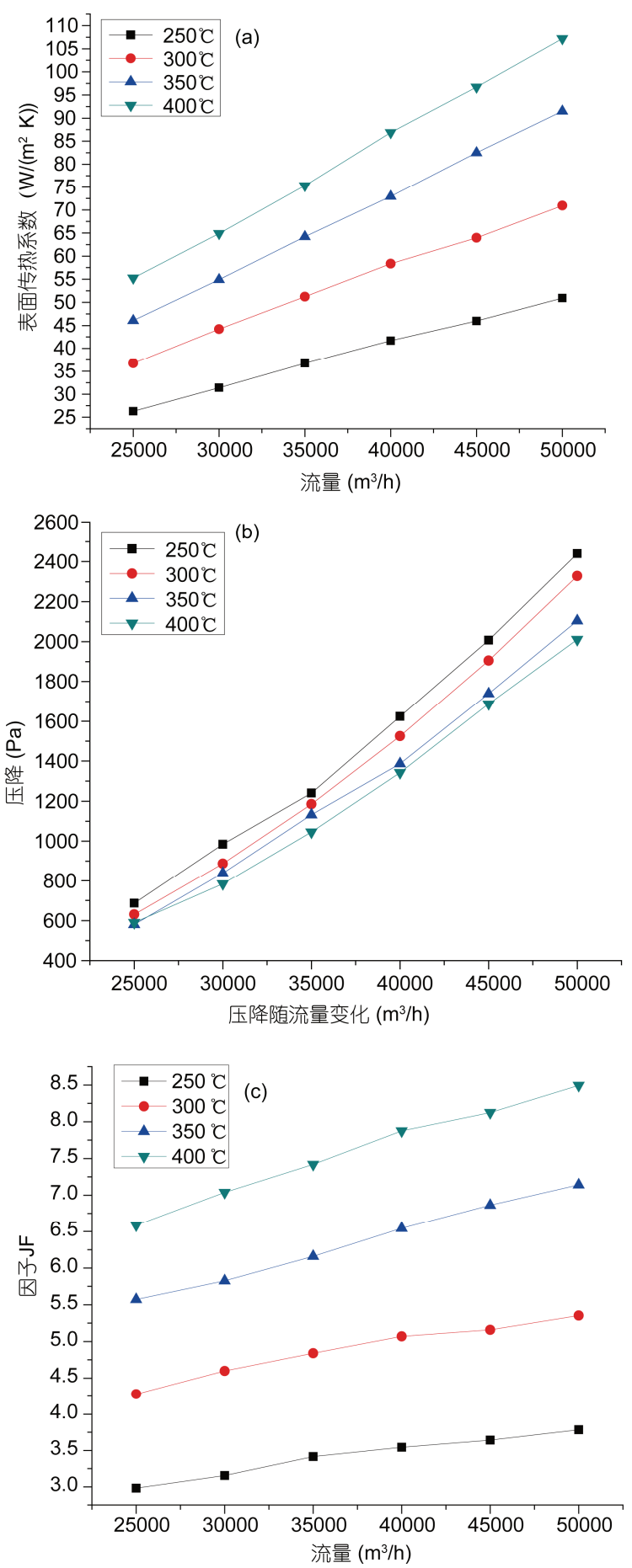

图 10 (网络版彩色)锅炉性能参数随流量的变化. (a) 表面传热系数; (b) 压降; (c) JF 因子

Figure 10 (Color online) Variation of performance parameters with the wind flow. (a) Convective heat transfer coefficient; (b) pressure drop; (c) JF factor

要大得多，虽然单位质量的压降增大，由于气体总量 大大减小, 因此随温度升高压降减小. 图9(c)给出了 
烟气侧JF因子随温度的变化曲线. 由此可知, 在相同 烟气流量下, 随温度升高JF因子增大. 对应的原因是 随温度升高表面传热系数增大压降减小, JF因子正比 于表面传热系数, 反比于压降的 $1 / 3$ 次方, 所以 JF因 子随温度升高而增大.

图10(a)为表面传热系数随烟气流量的变化曲线. 在相同温度下, 随流量增加表面传热系数增加. 分析 原因为流量增大则管间流速增大, 烟气紊流程度增 加, 管间对流传热过程更加剧烈, 因此对应的表面传 热系数增加. 图 10(b)为压降随流量变化曲线. 在相 同温度下, 随流量的增加压降增加. 分析原因为黏性 流体流动阻力近似正比于 $v$, 因此流量增大烟气速度 增大, 流体阻力增大, 压降增大. 图 10(c)给出了 JF因 子随流量变化的曲线, 由此可知在相同温度下, JF因 子随流量的增大而增大. 其原因为 JF因子正比于表 面传热系数, 反比于压降的 $1 / 3$ 次方, 由图 10 可知, 表面传热系数近似正比于流量, 压降近似正比于流
量的平方, 可以认为表面传热系数随流量增大的程 度比压降随流量增大的程度要大, 因此余热锅炉的 综合传热性能随烟气流量的增加而增加.

\section{3 结论}

本文以新型余热锅炉为对象, 采用数值方法研 究了余热锅炉的传热和流动特性, 相关结论如下.

(1) 提出了一种新的余热锅炉全尺寸数值模拟 方法, 实验验证了该方法的可靠性, 可用于相关余热 锅炉的数值计算中.

（2）在相同流量下, 随着烟气温度的升高, 余热 锅炉换热管外的表面传热系数增大，压降减小，JF因 子增大, 锅炉的综合传热性能提高. 在相同温度下, 随着烟气流量的增加, 余热锅炉换热管外的表面传 热系数增大, 压降增大, JF因子增大, 锅炉的综合传 热性能提高. 相关数值分析为这种新型余热锅炉的 运行和控制提供了参考.

\section{参考文献}

1 Jiang L X, Zhang N, Cai R X. Off-design performance analytical solution of superheated stream HRSG with single pressure (in Chinese). J Eng Thermophys, 1999, 20: 414-416 [江丽霞, 张娜, 蔡睿贤. 单压过热蒸汽余热锅炉变工况解析解. 工程热物理学报, 1999, 20: 414-416]

2 Cai R X, Hu Q. Off-design performance calculation of heat recovery steam generators (in Chinese). J Eng Thermophys, 1990, 11: 17-20 [蔡睿贤, 胡勤. 余热锅炉变工况计算. 工程热物理学报, 1990, 11: 17-20]

3 Xu Y J, Lin R M, Cai R X. A simple way for calculating the performance of combined cycles with non-additionally fired waste heat boilers (in Chinese). Power Eng, 2005, 25: 437-442 [徐玉杰, 林汝谋, 蔡睿贤. 无补燃余热锅炉型联合循环性能的简捷估算方法. 动力工程, 2005, 25: 437-442]

4 Liu F Q, Cao J C, Zhu D L. Thermo- economic optimization of heat recovery steam generators for BCHP systems (in Chinese). Gas Turb Technol, 2005, 18: 52-56 [刘凤强, 曹家枞, 朱冬林. BCHP 系统中余热锅炉结构参数的热经济学优化. 燃气轮机技术, 2005, 18: 52-56]

5 Cai H. Surface area design of waste heat boiler radiation heating surface of non-ferrous metallurgical furnace (in Chinese). Energy Conserv, 2000, 10: 14-16 [蔡晖. 有色冶金炉余热锅护辐射受热面面积的初步设计. 节能, 2000, 10: 14-16]

6 Wang S G. The heat rand analysis of the waste heat boiler (in Chinese). Equipment Manuf Technol, 2010, 8: 61-64 [王士国. 余热锅炉 的热力回收计算分析. 装备制造技术, 2010, 8: 61-64]

7 Zang X D, Liu Y Z, Yuan Y C. Experiment research of HRSG in energy island (in Chinese). Energy Res Util, 2005, (2): 49-51 [臓向东, 刘聿拯, 袁益超. 能源岛余热锅炉的实验研究. 能源研究与利用, 2005, (2): 49-51]

8 Liu Y Z, Xu S Y, Yuan Y C, et al. Experimental system for studying the characteristics of heat transfer and flow resistance of finned tube banks in heat recovery steam generator and its application (in Chinese). J Univ Shanghai Sci Technol, 2004, 26: $412-417$ [刘聿拯, 徐世 洋, 袁益超, 等. 余热锅炉换热元件传热与阻力特性模化实验系统研究. 上海理工大学学报, 2004, 26: 412-417]

9 Liu B, Li H, Li N, et al. Experiment study on ash deposition characteristic of convection heating surface in waste heat boiler (in Chinese). J Eng Thermophys, 2013, 2: 290-293 [刘博, 李辉, 李娜, 等. 余热锅炉对流受热面积灰特性的实验研究. 工程热物理学报, 2013, 2: 290-293]

10 Pei W, Wang S Z, Tong Z X. Experiment study of fouling process in inner surface of boiler tubes (in Chinese). J Eng Therm Energy Power, 2011, 5: 561-565 [裴炜, 王树众, 佟振霞. 锅炉管内腐蚀结垢过程的实验研究. 热能动力工程, 2011, 5: 561-565] 
11 Ma B, Ma Q L. Experimental research on high temperature superheater corrosion of biomass-fired boiler (in Chinese). J Anhui Electr Eng Prof Tech Coll, 2012, 3: 71-74 [马斌, 马启磊. 生物质直然锅炉高温受热面沉积垢的实验研究. 安徽电气工程职业学院学报, 2012, 3: 71-74]

12 Gómez A, Fueyo N, Díez L I. Modeling and simulation of fluid flow and heat transfer in the convective zone of a power-generat ion booler. Appl Therm Eng, 2008, 28: 532-546

13 Manickam M, Schwarz M P, Perry J. CFD modeling of waste heat recovery boiler. Appl Math Model, 1998: 823-840

$14 \mathrm{Xu}$ M, Azevedo J L T, Carvalho M G. Modeling of the combustion process and $\mathrm{NO}_{x}$ emission in a utility boiler. Fuel, 2000, 1611-1619

15 Yang Y, Jokilaakso A, Jarvi J, et al. Gas flow and cooling in waste-heat boilers in the outokumpu flash smelting process. Sulfide Smelting: Curr Fut Pract, 1998, 417-431

16 Zhou Z H, Peng P. Numerical simulations of gases flow in the inlet and outlet of the waste heat recovery boiler (in Chinese). Waste Heat Boiler, 2007, 1: 12-16 [周樟华, 彭鹏. 烟道式余热锅炉进出口烟道烟气流场数值模拟. 余热锅炉, 2007, 1: 12-16]

17 Cui C Y, Meng X Y, Duan Y F. Flow field optimization of the gas inlet of heat recovery steam generator (in Chinese). Boiler Manuf, 2006, 1: 26-27 [崔成云, 孟晓冬, 段跃非. 余热锅炉人口烟道流场优化. 锅炉制造, 2006, 1: 26-27]

18 Yang W H, Lai Y X, Xiao Z Q. Numerical simulation of flow and temperature fields in waste boiler (in Chinese). Chin J Nonferr Metal, 2000, 10: 278-281 [杨卫宏, 赖亚欣, 萧泽强. 余热锅炉流场温度场数值计算. 中国有色金属学报, 2000, 10: 278-281]

19 Yuan Y C, Tong Q H, Liu Y Z, et al. Numerical simulation on structure optimizing of inlet ducts in gas-steam combined cycle heat recovery steam generators (in Chinese). Boiler Technol, 2008, 39: 14-18 [袁益超, 全庆华, 刘聿拯, 等. 燃气-蒸汽联合循环余热锅炉 人口烟道结构优化数值模拟研究. 锅炉技术, 2008, 39: 14-18]

20 Song C H, Li L J. The numerical study on heat transfer problems of tube-mouth section (in Chinese). J Eng Therm Energy Power, 2003, 18: 391-393 [宋长华, 李隆键. 余热锅炉管口区传热的数值分析. 热能动力工程, 2003, 18: 391-393]

21 Yang Z, Liu Z L. Numerical simulation of HRSG inlet duct (in Chinese). Boiler Technol, 2007, 5: 1-3 [杨震, 刘忠楼. 余热锅炉人口烟 道数值模拟. 锅炉技术, 2007, 5: 1-3]

22 Yang C J, Chen E J, Cheng H, et al. Simulation of heat transfer of heat recovery boiler with additional out vents (in Chinese). Boiler Manuf, 2009, 3: 32-35 [杨杰程, 陈恩鉴, 程珩, 等. 余热锅炉增设放散烟道后的传热数值计算. 锅炉制造, 2009, 3: 32-35]

23 Song D G, Ding S, Ju X, et al. Simulation and optimization on radiation chamber of FF waste heat boiler in copper smelter (in Chinese). Nonferr Metal Eng Res, 2010, 31: 19-22 [宋冬根, 丁暏, 鞠霞, 等. 铜冶炼闪速炉余热锅炉辐射室的仿真与优化. 有色冶金设计与 研究, 2010, 31: 19-22]

24 Dong L L, Yuan Z F, Shen L C, et al. The mathematical simulation of three-dimensional heat transfer in a furnace of W-shape flame pulverized ceal boiler (in Chinese). J Zhejiang Univ (Nat Sci), 1997, 31: 547-554 [董否否, 袁镇福, 沈珞婵, 等. W 型火焰煤粉锅炉颅 内传热过程的二维数值模拟. 浙江大学学报, 1997, 31: 547-554]

25 Wu H F, Yuan Y C, Liu Y Z. Methods for investigation on dynamic characteristics of boilers (in Chinese). Energy Res Inform, 2009, 4: 198-203 [吴海凤, 袁益超, 刘聿拯. 锅炉动态特性研究方法综述. 能源研究与信息, 2009, 4: 198-203]

26 Cui N, Wang B S, Gao J Q, et al. Study and application on an dynamic model for the large capacity heat recovery steam generator (in Chinese). Proc CSEE, 2006, 26: 103-108 [崔凝, 王兵树, 高建强, 等. 大容量余热锅炉动态模型的研究与应用. 中国电机工程学报, 2006, 26: 103-108]

27 Chen W C, Li S F. Numerical calculation of dynamic performance of dual-pressure heat recovery steam generator (in Chinese). Energy Conserv, 2002, 3: 8-10 [陈维春, 李素芬. 余热锅炉动态特性的数值计算. 节能技术, 2002, 3: 8-10]

28 Qiu X J, Yang Y W, Lin Z D. Analysis of centrifugal stress for the $960 \mathrm{~mm}$ last stage blade of 500 MW super-critical steam turbine (in Chinese). Power Eng, 2002, 22: 2078-2083 [表浔隽, 杨瑜文, 林中达. 余热锅炉的动态数学模型及数字仿真. 动力工程, 2002, 22: 2078-2083]

29 Gao J Q, Hao N, Fan X Y, et al. Dynamic mathematical model and simulation for single-phase heat exchanger of heat recovery steam generator (in Chinese). J North China Electr Power Univ (Nat Sci), 2009, 5: 68-71 [高建强, 郝娜, 范晓颖, 等. 余热锅炉单相受热面 动态数学模型及仿真. 华北电力大学学报, 2009, 5: 68-71]

30 Xie L H, Zhao X Y, Zhang J M. ANSYS CFX Fluid Analysis and Simulation (in Chinese). Beijing: Publishing House of Electronics Industry, 2012. 12-13 [谢龙汉, 赵新宇, 张畑明. ANSYS CFX 流体分析及仿真. 北京：电子工业出版社, 2012. 12-13]

31 Du G S. Engineering Fluid Mechanics (in Chinese). Beijing: China Electric Power Press, 2007. 145-160 [杜广生. 工程流体力学. 北京: 中国电力出版社, 2007. 145-160]

32 Kim M S, Lee K S, Song S. Effects of pass arrangement and optimization of design parameters on the thermal performance of a multi-pass heat exchanger. Int J Heat Fluid Flow, 2008, 29: 352-363 


\title{
Full-scale numerical simulations on the performance of the heat recovery boiler used in the cement production process
}

\author{
DU WenJing ${ }^{1,2}$, ZHAO ChunLei $^{1} \&$ CHENG Lin ${ }^{1}$ \\ ${ }^{1}$ Institute of Thermal Science and Technology, Shandong University, Jinan 250061, China; \\ ${ }^{2}$ Department of Energy and Power Engineering, Shandong University, Jinan 250061, China
}

High-efficient and compound utilizations on industrial waste heat are becoming a hot issue because of the gradually tense energy uses situation. As a conventional waste heat recovery equipment, the heat recovery steam generator (HRSG) is accepted and applied in various fields. Many experimental researches are performed on the heat recovery boiler in order to obtain its corresponding heat recovery characteristics. In consideration of its complex structures and various powers, numerical simulations on the heat recovery boiler are still difficult assignments. In the former numerical simulation researches, numerous tubes in the heat recovery boiler are often simplified as porous medium, which can not reveal the actual temperature and flow distribution characteristics. The obtained numerical results cannot provide precise reference for the performance analyses and structure optimization of the heat recovery boiler. Therefore a kind of novel numerical simulation method on the heat recovery boiler is proposed in this paper. The heat recovery boiler under investigation is used for waste heat recovery in the cement production process. The corresponding heat source is imported from the outlet waste gases in the clinker cement cooler, whose temperature is generally ranging from around 150 centigrade to 400 centigrade. The waste heat is recovered by the cold water which will further increase the power of the waste heat power generation system. The full-scale numerical simulation model in this paper is simplified from the three dimension model to two dimension model because of the axial temperature difference along the heat transfer tube is often less than 1 centigrade. Typical experimental data testify that such simplification is feasible and applicable in the numerical simulation process. Characteristics of gas flow and heat transfer in the outside of the tube bundles are obtained, which are useful for the understanding of heat recovery performance in the heat recovery boiler. In the condition of prescribed changes of temperature and mass flow rate of the inlet exhaust gas, the performance of the heat recovery boiler is analyzed in details. And simultaneously the variation of the layout of tube bundles is also investigated, which include the aligned arrangement, the staggered arrangement and a novel rhombic arrangement. Results indicate that the comprehensive performance of the heat recovery boiler is improved with the increasing inlet exhaust gas temperature when the exhaust gas mass flow rate is kept as constant. And if the inlet exhaust gas temperature is unchanged, both the convective heat transfer coefficient and the pressure drop in the shell side will increase with the increase of gas mass flow rate. The corresponding JF factor in the shell side is also increased, which means an enhancement of the corresponding comprehensive performance in the heat recovery boiler. The full-scale method in this paper is universal for related numerical researches on the heat recovery boiler. Related conclusions can provide references and guidelines for similar numerical simulations researches of the heat recovery boiler. And a large quantity of numerical simulation results can provide data for the further optimized design and on line operation of the heat recovery boiler.

heat recovery boiler, numerical simulations, waste heat recovery

doi: $10.1360 / \mathrm{N} 972015-00462$ 